Manfred Dauster, Dr. iur.

Presiding Judge at the Bavarian Supreme Court

and at the High Court of Appeals in Munich

$7^{\text {th }}$ Criminal Panel for Criminal Cases of the Bavarian Supreme Court

$7^{\text {th }}$ Criminal Panel for National Security Related Cases of the High Court

of Appeals in Munich

Bavarian Supreme Court and

High Court of Appeals in Munich

Germany

\title{
VICTIMS OF CRIME AND CRIMINAL PROCEEDINGS IN GERMANY
}

\section{NOZIEGUMU UPURI UN KRIMINĀLPROCESS VĀCIJĀ}

\begin{abstract}
Kopsavilkums
Kriminālprocesā noziegumu upuriem jāpievērš īpaša uzmanība. Rūpes par tiem ir cilvēktiesību prasība. N̦emot vērā Eiropas Parlamenta un Padomes 2012. gada 25. oktobra Direktivvu 2012/29/ES, ar ko nosaka noziegumos cietušo tiesību, atbalsta un aizsardzíbas minimālos standartus, rakstā skatīts, kā Vācijas kriminālprocesa kodekss (un citas normas) risina to prasību nodrošināšanu, kas izriet no upuru īpašās situācijas.
\end{abstract}

Atslēgvārdi: upuru aizsardzības vēsture, cietušo papildu atbalsts kriminālprocesā, upuru aizsardzība kriminālprocesā, cietušie kā asociētie privātie prokurori

\begin{abstract}
Summary
Victims of crime need special attention in criminal proceedings. Care for such individuals is a human rights request. With a view upon Directive 2012/29/EU of the European Parliament and of the European Council of 25 October 2012 related to minimum standards of the rights, the support and the protection of victims of crime, the subsequent article will present how the Criminal Procedure Code of Germany (and other statutes) address the demands deriving from the victims' special situation.
\end{abstract}

Keywords: history of victim protection, victim support extra criminal proceedings, victim protection within criminal proceedings, victims as associate private prosecutors

\section{Introduction}

When goals of criminal proceedings are at stake, restoration of social peace disturbed and damaged by the committed crime is one of the primary and major basic purposes of prosecution and adjudication ${ }^{1}$. As such, this basic purpose furthermore represents a value of the social order established by the Basic Law of 1949 (hereafter

1 Fischer T. Strafgesetzbuch (hereafter StGB). $66^{\text {th }}$ edition, München, 2019, $\$ 46$ recitals 2, 2a; Kinzig Jörg. In: Schönke/Schröder, Strafgesetzbuch Kommentar. $30^{\text {th }}$ edition, München, 2019, $\$ 46$ recital 3 to 5 a. 
BL), Germany's 70-year-old constitution. As a part of constitutional order of values and of European tradition at least since the enlightenment, Germany places prosecution and adjudication of criminals exclusively within the jurisdiction of the public power and bans any form of private justice ${ }^{2}$ : Vigilantism is unethical ${ }^{3}$, unconstitutional, and therefore illegal. If vigilantism contravenes the German social order, it an ethical necessity to seek ways to address injuries suffered by crime victims. As individuals, they are not allowed to take revenge on perpetrators but need effective legal remedies in order to re-establish themselves within society and to re-find their individual social peace. Our views, though, may not focus exclusively on the defendant, whose guilt or innocence has to be established by state-performed prosecution. Any perpetration of crime produces victims. In terms of social peace restoration and preventing circumstances which may favour the uprising of vigilantism, criminal legislation must pay attention to the situation of victims of crime. Moreover, protection of human dignity ${ }^{4}$ does not tolerate any form of ignorance to crime victims under the regime of prosecution by the state. Hence, protection of human dignity urges state institutions, including courts, to pay diligent attention to victims of crime. It is not melodramatic to say: victims' protection is a human right, even though the Basic Law of Germany does not enshrine such right literally in the constitutional catalogue of fundamental rights.

Germany's legal history since the $19^{\text {th }}$ century abounds in responses to the question how persons to whom harm was inflicted by crime may participate in criminal proceedings in order to find conciliation ${ }^{5}$. In the period of the German Confederation 6 , before it was dissolved in 1866 as consequence of the 1866 German War, more than 30 German States (and [free] cities) had their own legislation on criminal proceedings resulting in various forms of 'private prosecution'. After the unification of Germany in 1871 and adoption of the then national unitary Criminal Procedure Code of 1 February $1877^{7}$ (hereafter CPC), "private prosecution" by individuals having suffered from harm by crime was common, but in the course of time lost its significance due to different reasons. Amending the CPC continuously over decades, the discussion among lawmakers and jurists from academia then considered abolishing all or only specific forms of participation of private persons in official criminal proceedings but such discussions remained without any feasible result ${ }^{8}$.

In the middle of the $20^{\text {th }}$ century, embedded in a broader scope of criminology, academia started to pay more attention to victims less from a legal point of view but

\footnotetext{
2 See Article 19 subsection 4 of the (German) Basic Law (hereafter BL $=$ Constitution of the Federal Republic of Germany) (BGBl. III Gliederungsnummer 100-1). In this context sharia justice within Muslim communities all over European countries are concerning. Its existence and effectiveness in Germany are not sufficiently researched yet but cannot be contested.

3 Höffe O. Lexikon der Ethik. $7^{\text {th }}$ edition, München, 2008, pp. 108, 109.

4 Article 1 subsection $1 \mathrm{BL}$.

5 Weigend T. Deliktsopfer und Strafverfahren. Berlin, 1989, p. 131.

6 Huber E. R. Deutsche Verfassungsgeschichte seit 1789. Band III: Bismarck und das Reich. Berlin, 3rd edition, Stuttgart, 1988, p. 576.

7 RGBl. 1877 pp. 253. Stern Klaus. Das Staatsrecht der Bundesrepublik Deutschland. Band V: Die geschichtlichen Grundlagen des deutschen Staatsrechts. München, 2000, p. 379.

8 Dauster M. Nebenklage und Beschuldigtenrechte: quo vadis? Commemorative Volume on the Occasion of the $70^{\text {th }}$ Birthday of Ottmar Breidling. Berlin, 2017, p. 43.
} 
more from a sociological perspective. In the early 1900s, the US sociologists and criminologists ${ }^{9}$ faced the challenge, and victimology became an increasingly important field of research within German criminology, too, and finally affected German legislation. This process was accompanied by respective developments on the international level, which, in the two last decades, were unfortunately caused by horrifying events globally. Dismantling Yugoslavia, for example, resulted in wars that contemporaries thought were gone forever with the cruelties of World War II. Recent global violent clashes give evidence of what human beings are capable of: homo hominem lupus est ${ }^{10}$. Furthermore, those conflicts, wherever they have happened, are happening, and will happen, prove the weakness of human living conditions and the necessity to support all afflicted individuals who innocently, often unconsciously and unintentionally, become the target of criminal activities. Thus, international criminal law institutions established in the last decade of the $20^{\text {th }}$ century had to take care of injured individuals ${ }^{11}$. Such attentiveness had repercussions on national legislation and was paralleled by responses to be given to the threats of national and international terrorism by legislation of the European Union, the Council of Europe and by the United Nations. All those phenomena, including the finding that very noxious forms of domestic crimes are no longer taboo (as, for example, sexual abuse offenses) and are seriously prosecuted, prove the need for a complex and comprehensive victim protection and support system in national criminal proceedings.

\section{Support and protection extra criminal proceedings}

Although this presentation aims at a closer look on the procedural position of victims in German criminal proceedings, it is worthwhile to consider some aspects that are not regulated by the German CPC.

1) The first Federal law that focused on victims with more attentiveness was the Federal Statute on Compensation to Victims of Crime of 15 May $1976^{12}$, which then was replaced by the current (Federal) Act on Compensation to Victims of Violent Crime ${ }^{13}$ of 7 January 1985. The aim of this normative act is to provide victims of violent assaults with compensation for injuries and economic

9 Hentig H., von. (The Criminal and His Victim, University Press Yale, New Haven 1948), Mendelsohn Benjamin and Ellenberg Henri, only as a few of exemplary representatives. von Mayenburg David, “Geborene Opfer” Bausteine für eine Geschichte der Viktimologie - Das Beispiel Hans von Hentig, Rechtsgeschichte Rg 14 Frankfurt, 2009, pp. 122-147. In Japan, Koichi Miyazawa was one of the important academia figures in victimology who was strongly influenced by German views (Kühne Hans-Heiner, Leben und Werk Koichi Miyazawas aus deutscher und internationaler Sicht, ZJapanR/J. JapanL Köln, 2011, p. 19.

10 Titus Maccius Plautus (ca. 254-184 b. c.), Asinaria; Hobbes Elementorum philosophiae sectio tertia de cive 1642; von der Pfordten Dietmar, Rechtsethik, $2^{\text {nd }}$ edition, München, 2011, pp. 320, 325.

11 See European Convention on the Compensation of Victims of Violent Crimes of 24 November 1983 (BGBl. 1996 II pp. 1920).

12 BGBl. 1976 I, pp. 1181.

13 BGBl. 1985 I, pp. 1. 
damages caused on German soil, vessels or aircrafts in the first place ${ }^{14}$ but also grants - under limited conditions - the same compensation even for harm inflicted abroad, ${ }^{15}$ which might be regarded as a natural consequence of global tourism and crime without borders. The law privileges German citizens and foreign nationals equally - however, under narrower conditions than those of the guarantee of reciprocity ${ }^{16}$, for example - and their descendants. ${ }^{17}$ Compensation also encompasses payment of pensions and reimbursement of costs for curative treatment and medical rehabilitation, including psychotherapies, glasses, contact lenses or dentures and other necessary equipment. ${ }^{18}$ Additional single payments round up the compensation system in case of loss of limbs ${ }^{19}$. Grounds for refusing compensation are listed in Section 2 and refer to the claimant's conduct resulting in the crime or in the injuries inflicted on him (for example, if the claimant was a member of organized crime and terror groups or a participant in struggles related to political conflicts in the home state). Compensation to victims of violent crime has to be seen as an element of social welfare and social welfare policy ${ }^{20}$. Thus, the implementation of the law is under the supervision of the Federal Ministry of Labor and Social Affairs ${ }^{21}$ and not within the jurisdiction of the Federal Ministry of Justice or the Federal Ministry for Consumers' Protection.

2) Practitioners observe that victims of crime, if such victims survive the assault, not only suffer from the harm that was inflicted upon them by the criminal, but are further hurt by the courtroom experience, as they have to give evidence under the procedural regime. Often enough they thereby turn from victims into witnesses under threat or into vulnerable witnesses. After an attack and/or after the apprehension of one or several attackers, the involved terror or organized crime organizations do not cease to exist and continue representing threat to those who report the crime committed by one of their members. The existence of such organizations represents a permanent threat and witnesses willing to testify against such gang members experience stress and feel abandoned and alone, even if the respective criminal organizations have not attempted to contact them. They may fear for their own or relatives' life and limbs, if they testify in court. Victims therefore are, in most of the cases, potential witnesses under threat and need protection not only when testifying in the courtroom but also outside the courthouse. Witness protection in Germany is barely provided for by German criminal procedure statutes, ${ }^{22}$ however, the matter of policing is regulated. 16 federal states and the central state of Germany have 17 different but mostly harmonized laws on police duties and its authority. Considering the utmost relevance of nation- and

14 Section 1 subsection 1 of Act on Compensation to Victims of Violent Crime.

15 Section 3a of Act on Compensation to Victims of Violent Crime.

16 Section 1 subsections 4, 5 and 6 of Act on Compensation to Victims of Violent Crime.

17 Section 1 subsection 8 of Act on Compensation to Victims of Violent Crime.

18 Section 1 subsection 10 of Act on Compensation to Victims of Violent Crime.

19 Section 3a subsection 2 of Act on Compensation to Victims of Violent Crime.

20 Bundestags-Drucksachen 7/2506, p. 9.

21 Section 6a subsection 1 of Act on Compensation to Victims of Violent Crime.

22 The presentation addresses the respective issues in greater procedural detail under Section III. 
countrywide witness protection, which may not cease at different states' borders, the Federal Republic of Germany on 11 December 2001 enacted the Federal Act on Harmonization of Witness Protection. ${ }^{23}$ Witness Protection in Germany is exclusively implemented by police authorities ${ }^{24}$ and is being carried out by special witness protection units within the police, which are strictly separated from the rest of the police, particularly from investigating units within the police ${ }^{25}$. The best solution is to segregate the units so that one unit does not know what the other is working on. Courts and prosecutors may initiate protection proceedings, but they fail to show a substantial influence on respective results or on the course of such proceedings. As in any other developed country, witness protection contains a wide range of protective measures from concealing the whereabouts of a person to changing the identity and other living conditions ${ }^{26}$. It is not necessary to further elaborate on details of witness protection by police but it is possible to summarize: victims are not properly protectable in the absence of a proper witness protection system.

3) Before harm has been inflicted on them, most of the victims have never set a foot into a courtroom. Summoned to the court in order to give evidence, they are usually afraid of the situation in the courtroom where they and their trauma will get exposed to public. Their understandable nervousness might even have an impact on their performance during cross examination and detract from their credibility. Most of such witnesses are well aware of such risks and do not know how to cope with them. Therefore, at least in the major German courts, administrative measures have been taken to support victims (and other vulnerable witnesses) prior to and during court hearings in particular in criminal cases: Witness Support Units are established by justice administration providing witnesses any in-housesupport they need. If so indicated, prior to hearings they are welcomed by court officials at the reception, guided to separate areas of the courthouse where they can relax, being cared of by officials who have special training. They are brought to the courtroom by those officials who, upon request of such witnesses, attend their hearing waiting in the courtroom outside the witness box. If they wish, those officials are obligated to attend to the vulnerable witnesses after their hearing is over and to give them the opportunity to talk about the (good or) bad experiences they have had during the witness examination.

4) Another extra procedural aspect has to be underlined. Most victims, particularly sexual assault victims, are reluctant to testify regarding intimate cruelties that they have experienced at the hands of perpetrators. On the other hand,

23 BGBl. 2001 I 3510. Herrmann Joachim. Die Entwicklung des Opferschutzes im deutschen Strafrecht und Strafprozessrecht - Eine unendliche Geschichte. ZIS 2010, pp. 236.

24 Article 2, par. 1, par. 2; Article 11, par. 1 of the Bavarian Law on Police Duties in consolidated version of 14 September 1990 (BayGVBl. 1990 pp. 397).

25 Witness Protection Files are strictly confidential. Nobody, including courts and prosecutors, has access thereto. They are not subject to inspection of files (Section 147 CPC) by the participants of proceedings.

26 See Article 94 of the Bavarian Law on Police Duties in consolidated version of 14 September 1990 (BayGVBl.1990 p. 397). 
the perpetrators often have an interest in avoiding a disclosure of their intimate life in a court proceedings when family members, friends, and neighbours attend. It is a win-win-situation for both sides to reach conciliation settlement outside the court proceedings, but it is becoming an essential procedural element in establishing guilt and measuring out penalties. Section 46a of the German Criminal Code (hereafter, $\mathrm{CC})^{27}$ provides that penalties of perpetrators might be mitigated if such perpetrators find a compensation settlement with the victim or attempt earnestly to settle the consequences of crime in favour of the victim ("perpetrator-victim-compensation"). In reality, such settlements cannot be reached without the perpetrator admitting his guilt as the transfer of compensating finances from the perpetrator onto the victim is only one side of the coin. Such settlements only make sense in terms of avoiding re-victimization if the perpetrator contributes his best to relieve the victim from the duty to testify in court and by doing so to eliminate the risk of getting re-traumatized. That is the other side of the settlement's coin. Such settlements have relevance in German court practice, especially in sexual assault cases related to minors and children, because they offer the defendant the chance to go away with mitigated penalties on the one hand, and guarantee the victim a chance to not face the perpetrator once again in a courtroom.

Those four extra procedural possibilities of victim protection and support are not exhaustive and do not represent a final enumeration of support means. However, the four examples should underline that the officials in charge should be inventive, if victim protection is at stake, and should not restrain themselves to those measures that are formally enacted by parliamentarian statutes. In general terms, it should be noted that prosecution authorities are not limited in their choice of means to such instruments that CPC expressively permits. Only if federal or state laws expressively forbid the use of specific means or instruments, prosecutors and courts are prevented from applying them $^{28}$. Otherwise, authorities are free in their selection of means that do not restrict other people in exercising their rights.

In this context of extra procedural support, civil society comes into play. Since the 1970s, as in many other European countries, private organizations which take care of crime victims came into existence. Courts and prosecutors are called upon to make use of their offers whenever public support service is not at hand or when post-court support is needed and not provided for. In Germany, the most renowned non-governmental organization offering victim support is "Der weiße Ring" (The White Ring). "Weißer Ring" was founded in 1976 and is nationally organized (a sister organization exists in Austria, as well) with about 50000 members. The organization's major goal is to provide support for victims, but it extends beyond this: besides the support of crime victims, the organization also works on crime prevention and public awareness of potential crime. It is financed not only by contribution of its members, but also by private and public donations, which often originate from the fines that courts or prosecutors impose on perpetrators.

27 Herrmann Joachim, l. c., ZIS, 2010, pp. 236/243 (see footnote 23).

28 See Section 160, subsection 4, CPC. 


\section{Procedural protection measures according to the German CPC}

The authority of trial judges commences at the entrance door to the courtroom and the courtroom walls often form the external boundary for exercising such authority. Within such limitations, judges should do their very best in order to minimize the pressure on vulnerable witnesses - the victims of crime. Empathy with the situation of such witnesses goes a long way toward helping them. In applying the needed empathy, CPC sets up guidelines, and CPC rules help to avoid secondary victimization of victims by procedure ${ }^{29}$.

\subsection{Recording victims' statements at the investigation phase}

a) Victims are vulnerable persons. In this light, Section 58a, section 1 of the German CPC considers the legal possibility of recording the statements given to an investigative judge in course of the investigation phase by minor witnesses who have been targets of sexual assault. Such recorded statements then can be used in the main trial to prevent re-traumatizing situations in the courtroom, when such vulnerable witnesses are summoned to testify directly ${ }^{30}$. The law considers such recorded statements as full evidence provided that the defendant and the defense counsel during the investigative phase have had the opportunity to be present when the underage witness testified before the investigative judge ${ }^{31}$. The scope of those provisions is limited. Although the protective effect of such recording is beyond any doubt, other vulnerable witnesses have to testify in courtroom. So far, there is a room for improvement.

b) It should be noted that Section 24 of the German Courts' Constitution Act (hereafter CCA) might, in this context, be an essential element of victim protection. This statute establishes criminal jurisdiction in the first instance - as a rule - on the level of district courts, unless the exceptional conditions as set down by Section 24, Section 1, No. 1, 2 and 3 are met. In such situations, the (higher) instance of regional courts exercise the first instance criminal jurisdiction with the procedural consequence that their verdicts become the subject of only legal review by the Federal Supreme Court of Justice ${ }^{32}$. One of the conditions of Section 24, subsection 1, No. 3 of CCA focusses on victims and declares regional courts to be competent, if victims are in need of special protection. If prosecutors file their indictments with regional courts due to such necessity, the vulnerable witness will give evidence only on that instance, and not before the district courts and

29 Psychology of witness hearing is a part of the training program for German judges and prosecutors, in particular, if such witnesses are of minor age. However, insufficient attention is paid to victims of crime in general. There is a space for improvement. Handling witnesses is neither a part of the university education in law schools nor is it an essential part of training of practitioners.

30 Section 255a, German CPC. For the conditions as set forth see Bertram Schmitt in Meyer-Goßner/ Schmitt, Strafprozessordnung, 61 ${ }^{\text {st }}$ edition '2018' München, $\$ 255$ a recitals 8-10.

31 Section 255a, subsection 2, sentences 1, 2 and 3 CPC.

32 Section 333 of the German CPC. The legal review by the Federal Supreme Court of Justice does take place upon a legally limited appeal, which might be compared to the request for "cassation", which is more common in the French and Italian legal systems. 
then - upon appeal - a second time before the appellate chambers of the regional courts. An improved victim protection is achieved as the consequence of reducing the number of times the vulnerable witness must testify.

\subsection{Witnesses' and victims' protection by limiting duties of such witnesses. Testifying in absence of the defendant}

a) Section 68, subsection 1 of CPC rules that a witness interrogation shall begin with questions on personal data referring to date of birth, profession etc., but also regarding the whereabouts of the witness. Vulnerable witnesses and victims are often afraid to disclose such information in a public hearing. Section 68 , subsections 2 to 5 of CPC set forth the conditions under which witnesses are allowed not to disclose such data. In this context, subsection 3 of Section 68 is of a special relevance. If there is a well-founded concern that in disclosing personal data about the identity and whereabouts of a person, life, limb or personal liberty of the witness or of another person are endangered, the witness/victim is legally permitted to remain silent. In terms of assessing the accuracy of such danger, courts need a factual basis. Of course, firstly, the victim has to describe such danger - not necessarily in the courtroom during his testimony but even outside the pending proceedings - unless such danger is obvious or known to security authorities. In order to establish that such danger exists or its existence is probable, the court needs threat assessments which are carried out by security-related authorities (police, intelligence institutions). It is then the Presiding Judge's decision at the main trial whether to permit the victim/witness not to disclose personal data. Such decisions may be contested by the participants in the proceedings. Such contests then are ruled upon by the judges' panel, and the panel's decision is not subject to an extra appeal to a higher instance court. ${ }^{33}$

Most witnesses or victims have not had any experience of being interrogated. Even if properly instructed on their rights, ${ }^{34}$ they may not dare to use or to understand them. That phenomenon is frequently to be found with regard to witnesses or victims with a foreign origin or from abroad. In terms of balancing their inabilities, Section 68b, subsection 1, sentence 1 of CPC permits such witnesses the assistance of a legal counsel for the purpose of the interrogation. If the concerned witness does not request such assistance but its necessity is indicated, the court in all phases of criminal proceedings may assign a legal counsel to such a person (Section 68b, subsection $2 \mathrm{CPC}$ ).

b) In cases related to foreign countries, which are continuously on the increase in Germany, courts are dealing with victims and witnesses who do not understand the language used in court. It is a human right to receive translation of court proceedings into the witnesses' mother tongue, if the witnesses do not understand German. Section 185, subsection 1, sentence 1 of CCA imposes upon the court

33 Section 305, sentence 1, CPC rules that decisions of the main trial court, which precede the verdict, may not be subject of an appeal but may only be appealed together with the verdict.

${ }^{34}$ Section 68, subsection 4, sentence 1, CPC. 
the duty to call in an interpreter to enable the witness or victim to communicate with the court and other persons participating in the proceedings.

c) Testifying in the presence of the defendant for vulnerable witnesses and victims is a nightmare. Many of them in this situation are exposed to the risk of re-traumatization. Moreover, in such situations they show nervousness and thus their credibility might be diminished. Hence, Section 247a, subsection 1 of CPC provides that the trial court may order that the witness may be heard from a place different from the courtroom if there is an otherwise high probability of grave consequences for the witness' well-being. Jurisprudence of the Federal Supreme Court of Justice establishes that Section 247a of CPC also covers even stricter protective measures, such as distortion of voice and physical appearance. Under the conditions set forth by Section 247a and Section 247 of CPC, the defendant may be removed from the courtroom if the court assumes that witnesses or coperpetrators have not been telling the truth in presence of the defendant. Since the application of Section 247 of CPC, there is a high potential of procedural mistakes. German court practice testifies that removal of defendants from the courtroom often results in procedural mistakes, which can serve as grounds for a successful appeal. Therefore, courts try to avoid removals and instead resort to other possibilities offered by Section 247a of CPC. Removal is seen as the ultimate instrument in getting witnesses to testify in a safe environment. In both alternatives, courts are rather restrictive, even though they know that victim protection cannot be carried out better. Judicial cautiousness in applying Sections 247 and 247a of CPC is based upon the fact that both provisions cause limitations to the right of defendants to a fair trial. Fair trial as a principle includes the defendant's right to confront witnesses, including victims, when giving evidence. If they are allowed to testify from a different place, or the defendant is removed from the courtroom for the time of their hearing, the right to confrontation might become less effective. The right to confrontation certainly suffers, if voice and physical appearance of the witnesses is distorted, since then the participants of the proceedings are no longer able to assess the witness' immediate reaction to questions asked to him/her. Judges are aware of such impacts of witness protection measure, but they equally acknowledge that in critical proceedings there is a need for these measures. In Germany, in such cases, courts try to rebalance the loss of defense rights by corroborating additional evidence from other sources or assess the credibility of such witnesses very carefully and thoroughly. The same is to be said if direct questioning of witnesses at the main trial is no longer possible and their statements are replaced by listening or looking to or at their statements previously recorded in earlier stages of criminal proceedings pursuant to Section $255 \mathrm{a}$ of CPC. 


\subsection{Victims as active participants in criminal proceedings}

a) Any treatment of victims ${ }^{35}$ should have the goal of rehabilitation, be it physical, psychological, financial or social. With a view to the legal and practical methodologies in implementing this goal, the German CPC has designated the victim as a full participant in the proceedings with all the necessary rights. Victims may join criminal proceedings as private accessory prosecutors in their own right (Section 395, paragraph 1 of CPC) and at any stage of the proceedings, ${ }^{36}$ if they were illegally harmed by criminal acts described by:

- Sections 174 to 182 of the Criminal Code (offences against sexual self-determination),

- Sections 211 and 212 of the Criminal Code, that was attempted (offences against life),

- Sections 221, 223 to 226 a and 340 of the Criminal Code (offences against bodily integrity),

- Sections 232 to 238, Section 239 subsection (3), Sections 239a and 239b, and Section 240 subsection (4) of the Criminal Code (offences against personal liberty),

- Section 4 of the Act on Civil Law Protection against Violent Acts and Stalking,

- Section 142 of the Patent Act, Section 25 of the Utility Models Act, Section 10 of the Semi-Conductor Protection Act, Section 39 of the Plant Variety Protection Act, Sections 143 to 144 of the Trade Mark Act, Sections 51 and 65 of the Designs Act, Sections 106 to $108 \mathrm{~b}$ of the Copyright and Related Rights Act, Section 33 of the Act on the Copyright of Works of Fine Art and Photography, and Sections 16 to 19 of the Act against Unfair Competition.

In those cases, the same right shall be vested in persons whose children, parents, siblings, spouse or civil partner were killed through an unlawful act, or who, through an application for a court decision (Section 172 of CPC) ) $^{37}$, have initiated the preference

35 German CPC does not use the term "victim". The legal wording is "injured person" (or "injured party") but in substance there is no difference in the meaning. For the perspective of Austria, see Moser Viktoria/Urban Bernd. Das Opfer im österreichischen Strafrecht. Ein Überblick. SIAK-Journal Zeitschrift für Polizeiwissenschaft und polizeiliche Praxis No. 3, Wien, 2017, pp. 18/21.

36 However, the course of proceedings having already commenced is not impeded by a late joinder (Section 398, CPC). Court decisions prior to joinder may not be appealed by any reason.

37 Particularly the victims, but also other persons who have witnessed the commitment of crime, may (in more serious crime constellations [Section $138 \mathrm{CC}$ ]) have to report the witnessed crime to the police or to other authorities. (Sections 158; 159, CPC). German criminal procedure is based upon the principle of legality (Section 152, subsection 2, CPC). The Prosecutor's Office thus has to investigate the (incriminating as well as exonerating) facts in order to prepare the decision, whether an indictment shall be filed pursuant to Section 170, subsection 1, CPC (Section 160, CPC). In all other cases, the public prosecution office shall terminate the investigative proceedings. If the public prosecution office does not grant an application for preferring public charges, or after conclusion of the investigation it orders the proceedings to be terminated, it shall notify the applicant, indicating the reasons. The decision shall inform the applicant, if he is at the same time the aggrieved person, of the possibility of contesting the decision and of the time limit provided thereof (Section 171). The victim may appeal such decision to the Prosecutor General (Section 172, subsection 1, CPC). If the Prosecutor General upholds the Prosecutor's decision on terminating the investigation without filing indictments victims may a request for judicial review with the Higher Regional Appellate Court (Section 172, subsections 2 
of public charges (Section 395, subsection 2 of CPC). If such victims declare joining the proceedings at any stage thereof (even at the stage of the appeal procedure [Section 395 , subsection 4 of CPC]), the court's decision on the joinder is only declaratory. Only in case of Section 395, subsection 3 of CPC, pursuant to which everybody who is aggrieved by another's unlawful act, in particular pursuant to Sections 185 to 189 (insult offences), Section 229 (negligent body injury), Section 244, subsection (1), number 3, Sections 249 to 255 and Section 316a of the Criminal Code (robbery offenses), may join the public prosecution as a private accessory prosecutor if, for particular reasons, especially because of the serious consequences of the act, this appears to be necessary to safeguard his interests, the court decides on the matter whether the declaration of joinder meets the conditions as set forth.

In terms of systematizing the rights of victims being entitled to joining the proceedings, the German law permits basic differentiations of the rights of private associate prosecutors. They are:

- The right to be informed about procedural rights of the victim in the proceedings (Section $406 \mathrm{~d}$; Section 406e CPC [right to inspect the files even before an indictment is filed]; Section 406i CPC) and proceedings (Section 397, subsection 1, sentence 5; Section 406d, subsection 3; Section 406j of CPC) at the earliest possible stage of the proceedings, in a language that the victims understand and even about the result of the proceedings and other circumstances that concern the victim (execution of criminal sanctions, release from prison, flight of the defendant [Section 406d, subsection 3 of CPC]);

- The right to be heard prior to court decisions (Section 397, subsection 1, sentence 4 of CPC);

- The right to be present at trial (Section 397, subsection 1, sentence 1 of CPC) with his counsel (Section 397, subsection 2, sentence 2 of CPC);

- The right to be advised by a legal counsel (Section 397, subsection 2 of CPC; Section 397a of CPC [in cases listed in subsection 1, the court may assign such a counsel ex officio, if the victim cannot afford a counsel financially and if the victim is not able to make use of the rights vested in him [subsection 2]; Section $406 \mathrm{f}$ of $\mathrm{CPC})$;

- The right to influence the course of the proceedings (disqualification of judges and expert witnesses, the right to question witnesses and expert witnesses, the right to object to procedural orders of the Presiding Judge or to object to questions of other participants in proceedings, the right to request to take additional evidence, and the right to comment on evidence already having been taken and to resume the results of the proceedings by final statement) (Section 397, subsection 1, sentence 3 of CPC); and, finally,

- The right to appeal court decisions prior to the verdict and to appeal the verdict but only to the extent of the crime, which permitted the joinder, and not aiming at a higher punishment (Section 400 of CPC).

including 4, CPC). In case of success of such a legal review, the Higher Regional Court orders the Prosecutor's Office to draft and file the indictment (Herrmann Joachim. 1. c., ZIS 2010, p. 236/240 [see footnote 23]; Moser Viktoria/Urban Bernd, 1. c., SIAK Journal - Zeitschrift für Polizeiwissenschaft und polizeiliche Praxis, 2017, pp. 18/23 [see footnote 35]). 
b) The associate private prosecutor may additionally pursue compensation to financial losses caused by the crime in question by jointly litigating against the defendant in same criminal proceedings (Section 403 of CPC). The defendant and the plaintiff may settle the claims by an agreement to be put on the records of the criminal proceedings (Section 405 of CPC). Otherwise, the criminal court will rule on the claims according to the conditions as set forth by Section 406, subsections 1 and 2 of CPC. This ruling is equally valid as a civil judgment (Section 406, subsection 3 of CPC) ${ }^{38}$.

c) On 1 January 2017, Section 406g by Federal Act on Improving Victims' Rights of 21 December 2015 entered into force ${ }^{39}$ and instituted psychosocial accompaniment as non-legal aid for victims $\mathrm{s}^{40}$. Although in several German states psychosocial accompaniment was practiced prior to the enactment of the law, the national legislator saw the countrywide need for such victim support, including caretaking, providing for information, and additional support in order to prevent secondary victimization of vulnerable individuals by the course of the proceedings $^{41}$. Academia ${ }^{42}$ did not entirely welcome such support, as it criticized the increasing number of different support sources for victims as a probable impediment to smooth management of criminal proceedings. Of course, psychosocial accompaniment overlaps already established witness support units at least within major courts. However, the law created a new denomination within forensic psychology ${ }^{43}$ and may help to manage witness support more professionally. Reliable data on how this works in practice is not yet available. Psychosocial accompaniment is a very new element of victim protection in the German court system. A thorough assessment of its successes, failures, or weaknesses will be made in future. Currently it is too early to arrive at any conclusions.

\section{Conclusions}

Victims in criminal proceedings in Germany have ceased to dwell in the shadows and neglect. Should they want it, the law provides them with the means of playing an active role in the prosecution ${ }^{44}$. The prosecution no longer focuses exclusively

38 Herrmann J. 1. c., ZIS p. 236/243 (see footnote 23).

39 BGBl. 2015 I 2525

40 Schmitt B. In: Meyer-Goßner/Schmitt, 1. c., \$ 406g recital 1 (see footnote 30); Moser Viktoria/Urban Bernd, l. c., SIAK-Journal - Zeitschrift für Polizeiwissenschaft und polizeiliche Praxis, 2017, p. 22 (see footnote 35).

${ }^{41}$ Schmitt B. In: Meyer-Goßner/Schmitt l. c. (see footnote 30); Bundestags-Drucksache 18/4621 p. 30.

42 Neuhaus R. Die Psychosoziale Prozessbegleitung nach dem 3. ORRG: Ein verhängnisvoller Irrweg. StV, Vol. 37, No. 1, Berlin, 2017, p. 55; Kett-Straub Gabriele. Wieviel Opferschutz verträgt das Strafverfahren? ZIS 2017, pp. 341, 342.

43 Art. 3 of Bavarian Law on Executing and Amending Criminal Provisions of 13 December 2016 (GVBl. 2016, S. 345). The 16 States of Germany have to establish the qualification requirements for people who like to become psychosocial companions professionally. Requirements include, for example, education of a psychotherapist with a long term practice over several years.

${ }^{44}$ Herrmann J. 1. c., ZIS 2010 pp. 236/245 (see footnote 23). 
on the defendant. The institution of private associate prosecutors is experiencing its "renaissance" in Germany. As far as I am able to overview the discussions related to victim protection, nobody seriously considers retracting and returning to the situation of 30 years ago. Internationally, we can see the same scheme with international criminal court institutions. The International Tribunals for the Former Yugoslavia and for Rwanda with their comprehensive understanding of witnesses and supporting victims have set their marks and those marks may guide developments within the scope of domestic criminal prosecutions.

However, interests of victims in prosecutions are not always identical with the goals that courts have to pursue. By law, criminal courts have not any interest in financial settlements, but victims might have such interests. Victim protection and speedy trials ${ }^{45}$ might conflict with each other. The more extensive the participation of victims in proceedings, the more difficult case management might become, especially if victims pursue different goals and do not harmonize their procedural activities. Such criminal proceedings are slower and therefore often more costly ${ }^{46}$. If lawmakers legislators consider reforms in the field of victim protection, they aim to streamline private associate prosecution in terms of limiting the number of participating legal counsel ${ }^{47}$ or to encourage victims to form interest groups ${ }^{48}$ wherever possible. It will be necessary to observe developments in that area in order to prevent that special form of victim support from failure and from becoming a "victim of the private associate prosecution's success" ${ }^{49}$.

\section{BIBLIOGRAPHY}

\section{Literature}

1. Dauster M. Nebenklage und Beschuldigtenrechte: quo vadis? Commemorative Volume on the Occasion of $70^{\text {th }}$ Birthday of Ottmar Breidling. Berlin, 2017, p. 43.

2. Fischer T. Strafgesetzbuch (mit Nebengesetzen). $66^{\text {th }}$ edition, München, 2019.

3. Hentig H., von. The Criminal and His Victim. University Press Yale, New Haven, 1948.

45 Article 6 subsection 1 of the European Convention on Human Rights.

46 Dauster M. 1. c., Commemorative Volume on the Occasion of $70^{\text {th }}$ Birthday of Ottmar Breidling, 2017, p. 43 (see footnote 8).

47 Pursuant to Section 397, subsection 2, CPC, the number of victims' legal counsel who may participate is not limited, unlike the number of chosen defense attorneys. Section 137 , subsection $1,2^{\text {nd }}$ sentence of CPC limits their number to not more than three.

48 Currently, the Regional Court of Oldenburg is sitting at trial against a male nurse who is charged of having killed more than one hundred elderly inmates of hospitals where he had worked. Due to the number of private associate prosecutors (members of the victims' families), the trial has become so large that the court could not find an adequate courtroom for all participants and moved the court into a local gym. 126 private associate prosecutors have joined the proceedings. In a terror-related case (NSU [Nationalsocialist Underground]), the Higher Court of Appeals in Munich prosecuted members of a right wing terror organization. Those members were charged of having killed foreigners and a police officer, of having robbed banks, and of having committed a bomb explosion. Around 70 relatives of the victims joined the proceedings and had been represented by 100 attorneys.

49 Herrmann J. 1. c., ZIS 2010, p. 236/245 warning that further reforms might turn the perpetrator into some sort of "victim" who becomes a forgotten figure of the criminal proceedings (see footnote 23). 
4. Herrmann J. Die Entwicklung des Opferschutzes im deutschen Strafrecht und Strafprozessrecht - Eine unendliche Geschichte. ZIS 2010, pp. 236.

5. Höffe O. Lexikon der Ethik. $7^{\text {th }}$ edition, München, 2008.

6. Huber E. R. Deutsche Verfassungsgeschichte seit 1789. Band III: Bismarck und das Reich. $3^{\text {rd }}$ edition, Stuttgart, 1988.

7. Kett-Straub G. Wieviel Opferschutz verträgt das Strafverfahren? ZIS 2017, p. 341.

8. Kühne H.-H. Leben und Werk Koichi Miyazawas aus deutscher und internationaler Sicht, ZJapanR/J.JapanL. Zeitschrift für Japanisches Recht (Journal of Japanese Law), Köln, 2011, p. 19.

9. Mayenburg D., von. “Geborene Opfer” Bausteine für eine Geschichte der Viktimologie - Das Beispiel Hans von Hentig. Rechtsgeschichte Rg 14, Frankfurt, 2009, pp. 122-147.

10. Meyer-Goßner L., Schmitt B. Strafprozessordnung Kommentar. 61 ${ }^{\text {st }}$ edition, München, 2018.

11. Moser V., Urban B. Das Opfer im österreichischen Strafrecht. Ein Überblick. SIAK-Journal Zeitschrift für Polizeiwissenschaft und polizeiliche Praxis, No. 3, Wien, 2017, p. 18

12. Neuhaus R. Die Psychosoziale Prozessbegleitung nach dem 3. ORRG: Ein verhängnisvoller Irrweg. StV, Vol. 37, No. 1, Berlin, 2017, p. 55.

13. Pfordten D., von der. Rechtsethik. $2^{\text {nd }}$ edition, Munchen, 2011.

14. Schönke A., Schröder H. Strafgesetzbuch Kommentar. 30 ${ }^{\text {th }}$ edition, München, 2019.

15. Stern Klaus. Das Staatsrecht der Bundesrepublik Deutschland. Band V: Die geschichtlichen Grundlagen des deutschen Staatsrechts. München, 2000.

16. Weigend T. Deliktsopfer und Strafverfahren. Berlin, 1989.

\section{GLOSSARY}

BayGVBl. Bayerisches Gesetz- und Verordnungsblatt (Official Gazette of the Free State of Bavaria)

RGBl. Reichsgesetzblatt (Gazette of the German Reich)

BGBl. Bundesgesetzblatt (Federal Gazette)

BGBl. I Bundesgesetzblatt/Teil I (Federal Gazette Part I [national statutes])

BGBl. II Bundesgesetzblatt/Teil II (Federal Gazette Part II [international treaties and other international instruments related to Germany])

BGBl. III Bundesgesetzblatt/Teil III (Federal Gazette Part III [national statutes in their actual and updated versions])

Bundestags-

Drucksachen Protocols of the Sessions of the German Bundestag (= German Parliament) 